\title{
Permanganate Degradation of Reillex HPQ Ion Exchange Resin for Use in HB-Line
}

by

B. W. Walker

Westinghouse Savannah River Company

Savannah River Site

Aiken, South Carolina 29808

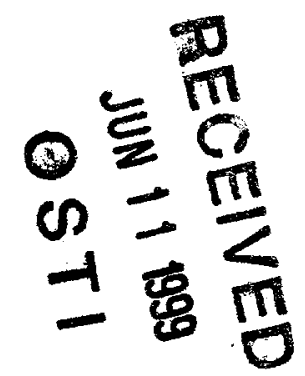

DOE Contract No. DE-AC09-96SR18500

This paper was prepared in connection with work done under the above contract number with the U.S.

Department of Energy. By acceptance of this paper, the publisher and/or recipient acknowledges the U.S. Government's right to retain a nonexclusive, royalty-free license in and to any copyright covering this paper, along with the right to reproduce and to authorize others to reproduce all or part of the copyrighted paper. 


\section{DISCLAIMER}

This report was prepared as an account of work sponsored by an agency of the United States Government. Neither the United States Government nor any agency thereof, nor any of their employees, makes any warranty, express or implied, or assumes any legal liability or responsibility for the accuracy, completeness, or usefulness of any information, apparatus, product, or process disclosed, or represents that its use would not infringe privately owned rights. Reference herein to any specific commercial product, process, or service by trade name, trademark, manufacturer, or otherwise does not necessarily constitute or imply its endorsement, recommendation, or favoring by the United States Government or any agency thereof. The views and opinions of authors expressed herein do not necessarily state or reflect those of the United States Government or any agency thereof.

This report has been reproduced directly from the best available copy.

Available to DOE and DOE contractors from the Office of Scientific and Technical Information, P.O. Box 62, Oak Ridge, TN 37831; prices available from (615) 576-8401.

Available to the public from the National Technical Information Service, U.S. Department of Commerce, 5285 Port Royal Road, Springfield, VA 22161. 


\section{DISCLAIMER}

Portions of this document may be illegible in electronic image products. Images are produced from the best available original document. 
Westinghouse Savannah River Company

Savannah River Technology Center

Keywords: Ion Exchange Resin, H B-Line, KMnO4 Digestion

Retention: Permanent

Permanganate Degradation of Reillex HPQ Ion Exchange Resin for use in H B-Line

December 21, 1998

B.W. Walker, 773-43A

Savannah River Technology Center

Westinghouse Savannah River Company

Aiken, SC 29808 


\section{Summary}

This study evaluated the use of Reillex TM HPQ resin as a replacement for the Ionac A-641 resin currently authorized for use in H B-Line. The study concentrated on the ability of the existing alkaline permanganate digestion process to convert spent resin for disposal. The work reached the following conclusions:

- Digestion per the current process parameters for 15 hours at $70^{\circ} \mathrm{C}$ with

$1 \mathrm{~kg} /$ liter permanganate reacted $82 \%$ of the Reillex resin as detected by Total Organic Carbon and Total Inorganic Carbon methods.

- This digestion rate compares favorably with the historical studies on Permutit SK resin having a similar chemical structure ( $82 \%$ destruction in 20 hours reported by Snyder) ${ }^{1}$ and Dowex MSA-1 resin having the same chemical formula as the Ionac A641 resin now qualified for plant use ( $99 \%$ destruction in 12 hours reported by Wehner) ${ }^{2}$.

\section{Introduction}

The HB-Line at the Savannah River Site uses ion exchange columns to extract $\mathrm{Pu}$ and $\mathrm{Np}$ from process streams. Engineering requested that the Savannah River Technology Center (SRTC) qualify a Reillex ion exchange resin (1-methyl-4-vinylpyridine/styrene/ Divinylbenzene, $\mathrm{C}_{9} \mathrm{H}_{12} \mathrm{~N}$ ) for plant process applications. ${ }^{1,2}$ This resin performs better than Ionac A-641 resin (benzyltrimethyl/styrene/divinyl benzene resin, $\mathrm{C}_{12} \mathrm{H}_{18} \mathrm{~N}$ ) currently qualified for use in the plant in part due to increased resistance to degradation from nitric acid and radiation.

Spent process resin disposal relies on destruction of degraded resin with alkaline permanganate. Destruction proves necessary in part due to corrosion concerns that arise since resin degradation through radiation and chemicals in the waste tanks cause formation of carbon dioxide leading to neutralization of the waste and increased corrosion rates. Qualification of the Reillex TM HPQ resin requires that it digest in alkaline permanganate media similar to other resins previously used in the plant.

This study examined whether the current plant alkaline digestion procedure adequately destroys a resin for use in $\mathrm{H}$ B-Line ion exchange columns recovering plutonium and neptunium. After exposure of plant resin to radiation, personnel flush the resin from the column with $8 \mathrm{M} \mathrm{HNO}_{3}\left(17 \mathrm{~L}\right.$ of $\mathrm{HNO}_{3} / \mathrm{L}$ resin). Sixteen liters of $0.39 \mathrm{M} \mathrm{KMnO}_{4}$ is added per liter of resin ( $1 \mathrm{~kg} \mathrm{KMnO}_{4}$ added per liter of resin). The process involves heating to $71-76^{\circ} \mathrm{C}$ for 15 hours, during which time the resin oxidizes to carbon dioxide and soluble carbon compounds, while the permanganate converts to insoluble $\mathrm{MnO}_{2}$. After cooling to $50^{\circ} \mathrm{C}$, personnel add $2.7 \mathrm{~L}$ of $19 \mathrm{M} \mathrm{NaOH}$ per liter of resin to 
adjust the mixture to $1.2 \mathrm{M} \mathrm{NaOH}$ before sending the solution to the waste farm. The process generates a total liquid waste volume of approximately $43 \mathrm{~L}$ per liter of resin.

The plant digestion procedure evolved from studies conducted in 1962 that specified flushing the spent resin from the column with about four resin volumes of $26 \% \mathrm{NaNO}_{3}$; the most recent operations flush the resin from the column with about 17 resin volumes of $8 \mathrm{M} \mathrm{HNO}_{3}$. This change with the $\mathrm{NaOH}$ added to neutralize the $\mathrm{HNO}_{3}$, dilutes the reaction mixture and slows the digestion rate. For this reason, the plant digestion procedure reaction time was increased to the current time of 15 hours instead of the original 6 hours specified in the Technical Standards.

\section{Experimental}

Figure 1 is a diagram of the experimental apparatus.

\section{Figure 1. Apparatus Diagram}

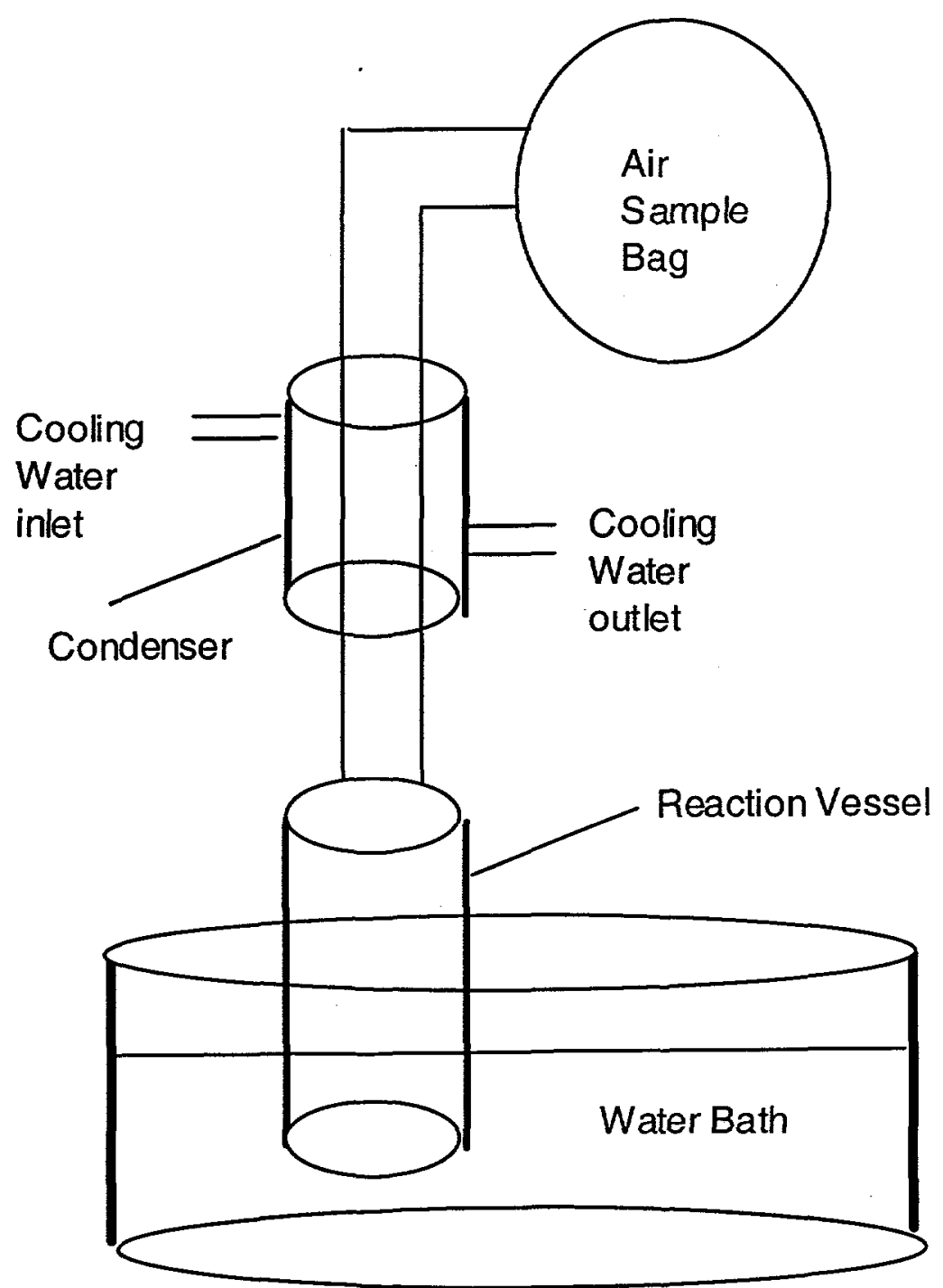


Figure 2 provides a picture of the experimental apparatus.

\section{Figure 2. Apparatus Picture}

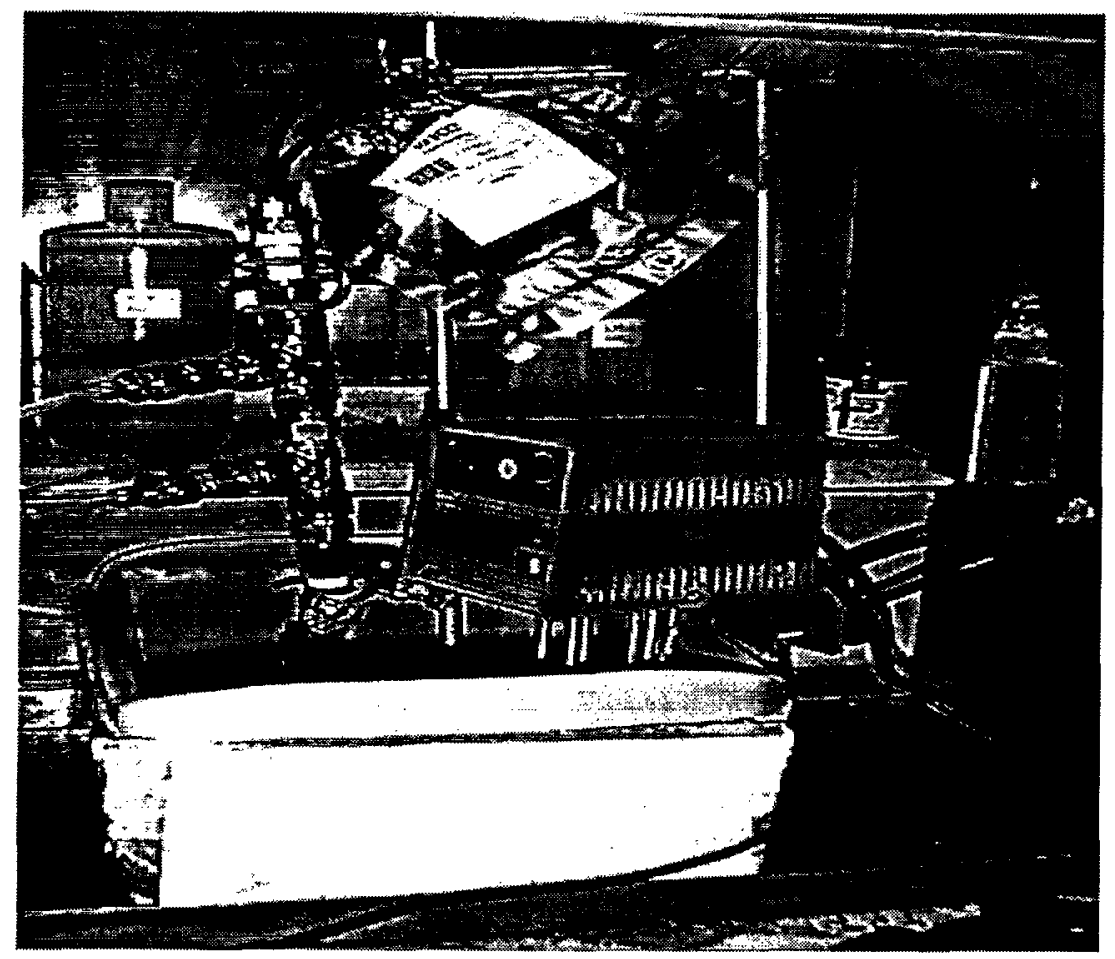

To a $2 \mathrm{~mL}$ resin sample in the reaction vessel, $33.7 \mathrm{mLs}$ of $8 \mathrm{M}$ HNO3 was added. This mixture was neutralized with $14.2 \mathrm{mLs}$ of $19.1 \mathrm{M} \mathrm{NaOH}$, and the $\mathrm{pH}$ adjusted with $\mathrm{HNO}_{3}$ or $\mathrm{NaOH}$ to approximately 8 . Next, $32 \mathrm{mls}$ of $0.39 \mathrm{M} \mathrm{KMnO}_{4}$ was then added, and the mixture placed in a water bath maintained at $70^{\circ} \mathrm{C}$ for either 5,10 , or 15 hours. After digesting for the specified time the solution was then cooled in an ice bath and $5.4 \mathrm{mLs}$ of $19.1 \mathrm{M} \mathrm{NaOH}$ added to adjust the solution to $1.2 \mathrm{M} \mathrm{NaOH}$. The solution was filtered to separate the filtrate and precipitate which were then analyzed for organic and inorganic carbon content to determine the amount of resin digestion.

Initially all gases evolved during the digestion were retained in the reaction vessel and attached sample bag. At the end of digestion samples of the vapor were collected from a sample port attached to the reaction vessel using a syringe and analyzed by gas chromatograph and mass spectrophotometer instrumentation. These analyses revealed only small amounts of $\mathrm{CO}_{2}$ and acetone present in the vapor over the digested resin. The vapor $\mathrm{CO}_{2}$ accounted for $0.41 \%$ and the vapor acetone $0.28 \%$ of the total resin carbon in 
the original sample. Since these amounts were so small $(<1 \%)$ the resin was digested in a flask covered with a watch glass to minimize evaporation in the remaining experiments instead of the closed system with reflux condenser.

It was observed during the first part of the experiment that $\mathrm{KMnO}_{4}$ reagent degrades to a great extent after only a few days in solution. To avoid this problem, the $\mathrm{KMnO}_{4}$ reagent was made fresh for the remainder of the study for each digestion. Dry $\mathrm{KMnO}_{4}$ powder and water were added directly to the sample to be digested at the beginning of digestion so no reagent degradation could occur.

\section{Results and Discussion}

Resin digestion results in the formation of $\mathrm{CO}_{2}$ and soluble organic compounds. The $\mathrm{CO}_{2}$ levels in both the precipitate and filtrate of the digestion mixture were determined by total inorganic carbon analyses. The total amount of soluble organic compounds in the filtrate of the digestion mixture was determined by total organic carbon analyses. The amount of resin carbon left undigested is determined by adding the grams of carbon from soluble organic compounds in the filtrate, grams of $\mathrm{C}$ from $\mathrm{CO}_{2}$ in both the precipitate and filtrate of the digestion mixture and subtracting from the grams of carbon in the resin.

Ratios of carbon to resin were determined from the formulas for each resin and used in calculating the amount of carbon in the original sample. The ratio of carbon to Reillex TM HPQ resin is $108 \mathrm{~g}$ carbon to 134 grams of resin. This is derived from the resin formula being $\mathrm{C}_{9} \mathrm{H}_{12} \mathrm{~N}$. The weight of carbon $=9 \times 12=108$ grams and the weight of resin $=9 \times 12+12+14=134$ grams. The ratio of carbon to Ionac A-641 resin is 144 grams of carbon to 176 grams of resin. This is derived from the resin formula being $\mathrm{C}_{12} \mathrm{H}_{18} \mathrm{~N}$. The weight of carbon $=12 \times 12=144$ grams and the weight of resin $=12 \times 12+14+18=176$ grams.

Reillex TM HPQ resin likely dissolves by primary attack on the tertiary carbon at crosslinks and some oxidation of the amine functional group. The residual functional groups probably enhance solubility of the larger molecular fragments. Benzene is less subject to oxidation than pyridine (the resonance stabilization is greater and the ionization potential is higher for benzene than for pyridine). However, Reillex TM HPQ resin is less easily oxidized than Ionac A-641 because the quaternary amine is more susceptible to oxidation than the methyl-pyridinium type compound in Reillex TM HPQ (as suggested by ionization potentials of tertiary amines and pyridine). This explains the higher \% oxidation of Ionac A-641 at $98 \%$ (aromatic compound) versus the Reillex TM HPQ percentage of $82 \%$ (pyridine compound).

Sample \#1 digested at conditions of 15 hours, $70^{\circ} \mathrm{C}$, with $1 \mathrm{~kg} \mathrm{KMnO} /$ liter of resin used the same day it was made gave results similar to those from previous studies. Samples 2,3 , and 4 did not digest the resin to levels anticipated. The poor digestion resulted from degradation of the $\mathrm{KMnO}_{4}$ reagent after only 2 or 3 days. Digestion results similar to previous studies were obtained with samples 5, 6, 7, and 8 when $\mathrm{KMnO}_{4}$ and water were 
added to resin samples immediately before digestion. Total Organic Carbon results in line with previous studies results were obtained with samples $9,10,11,12,13$, and 14 but lower than expected Total Inorganic Carbon results were reported by SRTC Analytical testing. The analytical section at SRTC attributes the lower than expected Total Inorganic Carbon results to the samples being overly basic. Total Inorganic Carbon analysis requires using phosphoric acid to acidify the sample which drives off the inorganic carbon as $\mathrm{CO}_{2}$. If the sample is overly basic there is not enough acid to drive off all the carbon as $\mathrm{CO}_{2}$.

Table 1 gives digestion results that agreed with results obtained from previous studies. Samples 2,3, and 4 which had degraded $\mathrm{KMnO}_{4}$ and samples $9,10,11,12,13$, and 14 that had low Total Inorganic Carbon solution results caused by possible overly basic solutions are not included in Table 1. Raw analytical results obtained from all samples digested are given in the Appendix.

\section{Table 1. Digestion Study Results for Reillex TM HPQ Resin Qualification}

\begin{tabular}{|c|c|c|c|c|}
\hline $\begin{array}{l}\text { Soln } \\
\% \mathrm{C} \text { as } \\
\mathrm{CO} 2 \mathrm{C} \\
\end{array}$ & $\begin{array}{l}\text { Soln } \\
\% \mathrm{C} \text { as } \\
\text { Soluble C } \\
\end{array}$ & $\begin{array}{l}\mathrm{PPT} \\
\% \mathrm{C} \text { as } \\
\mathrm{CO} 2 \mathrm{C} \\
\end{array}$ & $\begin{array}{l}\text { Total \% } \\
\text { C Digested }\end{array}$ & $\begin{array}{l}\text { Resin Test } \\
\text { Conditions }\end{array}$ \\
\hline 53.3 & 19.6 & 2.1 & 71.7 & $\begin{array}{l}\text { Reillex, } 7 \mathrm{hrs}, 70^{\circ} \mathrm{C} \\
1 \mathrm{~kg} \mathrm{KMnO} / \text { /liter of resin }\end{array}$ \\
\hline 62.5 & 8.5 & 3.1 & 70.7 & $\begin{array}{l}\text { Reillex, } 5 \mathrm{hrs}, 70^{\circ} \mathrm{C} \text {, } \\
1 \mathrm{~kg} \mathrm{KMnO} / \text { liter of resin }\end{array}$ \\
\hline 63.4 & 6.2 & .7 & 67.1 & $\begin{array}{l}\text { Reillex, } 10 \mathrm{hrs}, 70^{\circ} \mathrm{C} \\
1 \mathrm{~kg} \mathrm{KMnO}{ }_{4} / \text { liter of resin }\end{array}$ \\
\hline 67.7 & 18.1 & 0 & 81.8 & $\begin{array}{l}\text { Reillex, } 15 \mathrm{hrs}, 70^{\circ} \mathrm{C} \\
1 \mathrm{~kg} \mathrm{KMnO} / \text { liter of resin }\end{array}$ \\
\hline 49.5 & 48.8 & 0 & 98.3 & $\begin{array}{l}\text { Ionac, } 15 \mathrm{hrs}, 70^{\circ} \mathrm{C} \text {, } \\
1 \mathrm{~kg} \mathrm{KMnO} / \text { /liter of resin }\end{array}$ \\
\hline
\end{tabular}

The Ionac A-641 resin digestion results of $98 \%$ agree well with those obtained by Wehner with Dowex MSA-1 resin (same chemical structure). The Reillex TM HPQ resin digestion results were in the same range as those obtained by Snyder with Permutit resin (pyridine resin with similar chemical structure). 
Table 2 summarizes the results obtained in previous digestion studies.

\section{Table 2. Previous Permanganate Digestion Study Results for Resin Qualification}

Wehner (DPST-88-569) ${ }^{2}$

\begin{tabular}{|c|c|c|c|c|}
\hline Soln & Soln & PPT & & \\
\hline$\% \mathrm{C}$ as & $\% \mathrm{C}$ as & $\% \mathrm{C}$ as & Total \% & Resin Test \\
\hline $\mathrm{CO} 2 \mathrm{C}$ & $\underline{\text { Soluble C }}$ & $\mathrm{CO} 2 \mathrm{C}$ & $\underline{C \text { Digested }}$ & Conditions \\
\hline $\begin{array}{l}\text { Not } \\
\text { known }\end{array}$ & $\begin{array}{l}\text { Not } \\
\text { known }\end{array}$ & $\begin{array}{l}\text { Not } \\
\text { known }\end{array}$ & 99. & $\begin{array}{l}\mathrm{MSA}-1,15 \mathrm{hrs}, 70^{\circ} \mathrm{C} \\
1 \mathrm{~kg} \mathrm{KMnO} / \\
\text { liter of resin }\end{array}$ \\
\hline
\end{tabular}

Snyder (DP-717) ${ }^{1}$

\begin{tabular}{|c|c|c|}
\hline $\begin{array}{l}\text { Not } \\
\text { known }\end{array}$ & $\begin{array}{l}\text { Not } \\
\text { known }\end{array}$ & $\begin{array}{l}\text { Not } \\
\text { known }\end{array}$ \\
\hline
\end{tabular}

Table 1 shows that a larger proportion of the Ionac A-641 resin reacts during alkaline permanganate digestion to give soluble organic carbon in the filtrate than Reillex TM HPQ at the same conditions.

\section{Conclusions}

Digestion of Reillex TM HPQ resin for 15 hours at $70^{\circ} \mathrm{C}$ before the manufacturer modified the process reacted $82 \%$ of the resin carbon. This agrees with digestion results obtained by SRTC with Permutit SK resin having a similar chemical structure (82\%). Digestion of Ionac A-641 resin for 15 hours at $70^{\circ} \mathrm{C}$ reacted $98.3 \%$ of the resin carbon. This agrees with SRTC digestion results of Dowex MSA-1 resin (99\%) having the same chemical structure as Ionac A-641 which is currently qualified for use in H B-Line digestion operations.

Two digestion trials of Reillex TM HPQ resin received after the manufacturer modified the resin process resulted in lower resin carbon digestion percentages than expected (see Samples 13 and 14 in the Appendix). One possible explanation for lower carbon digestion results could be because the filtrate from the samples was overly basic. Total Inorganic Carbon analysis requires using phosphoric acid to acidify the sample which drives off the inorganic carbon as $\mathrm{CO}_{2}$. If the sample is overly basic there is not enough acid to drive off all the carbon as $\mathrm{CO}_{2}$ and the analytical results would be less than actual.

Further tests of the resin made with the modified process should probably be done to confirm or disprove the lower digestion values obtained. 


\section{References}

1. Snyder, M. D., "Dissolution of Ion Exchange Resins in Alkaline Permanganate", DP717, Savannah River Laboratory, July, 1962.

2. Wehner, J. A., "Permanganate Dissolution of Macroporous Anion Exchange Resin", DPST-88-569, Savannah River Laboratory, May 19, 1988.

3. Vohden, R. A., "Technical Task Request", TTR 97-NMPD/SHE-0081, NMS\&S, March 23, 1997.

4. Walker, B. W. "Technical Task Plan for HB-Line Resin Qualification", March 17, 1998.

5. Laboratory Notebook WSRC-NB-96-633. 


\section{Author}

$\begin{array}{ll}\text { P. W. Walken } & 2-3-99 \\ \text { B.W. Walker } & \text { Date }\end{array}$

\section{Design Check}

$\frac{\text { OQThyme }}{\text { E.A. Kyser, } 773-A}$

\section{Approvals}

$\frac{\text { W.B. Van felt }}{\text { W.B. Van Pelt, Level 4 Manager, Waste Processing Technology }}$


APPENDIX

\begin{tabular}{|c|c|c|c|c|c|c|c|}
\hline $\begin{array}{l}\text { PPM } \\
\text { SolnC } \\
\text { TIC }\end{array}$ & $\begin{array}{l}\text { PPM } \\
\text { SolnC } \\
\text { TOC }\end{array}$ & $\begin{aligned} & \text { PPM } \\
& \text { C PPTC } \\
& \text { TIC }\end{aligned}$ & $\begin{array}{l}\text { Grams } \\
\text { C Soln } \\
\text { TIC }\end{array}$ & $\begin{array}{l}\text { Grams } \\
\text { C Soln } \\
\text { TOC }\end{array}$ & $\begin{array}{l}\text { Grams } \\
\text { C PPT } \\
\text { TIC }\end{array}$ & $\begin{array}{l}\text { Grams } \\
\text { Resin } \\
\text { C }\end{array}$ & $\begin{array}{l}\text { Resin Test } \\
\text { Conditions } \\
\end{array}$ \\
\hline 3628 & 1332 & 3338 & .298 & .109 & .0125 & .612 & $\begin{array}{l}\text { Reillex, } 7 \mathrm{hrs}, 70^{\circ} \mathrm{C} \text {, } \\
1 \mathrm{~kg} \mathrm{KMnO} / \text { liter of resin } \\
\text { (fresh), Sample } 1,82 \mathrm{~g} \text { soln, } \\
3.732 \mathrm{~g} \text { wet ppt }\end{array}$ \\
\hline 189 & 743 & 1833 & .0155 & .061 & .00453 & .536 & $\begin{array}{l}\text { Reillex, } 10 \mathrm{hrs}, 70^{\circ} \mathrm{C} \\
1 \mathrm{~kg} \mathrm{KMnO} / \text { liter of resin } \\
\text { (degraded), Sample } 2,82 \mathrm{~g} \\
\text { soln, } 2.471 \mathrm{~g} \text { wet ppt }\end{array}$ \\
\hline 1915 & 695 & 1728 & .1532 & .0556 & .0076 & .544 & $\begin{array}{l}\text { Reillex, } 15 \mathrm{hrs}, 70^{\circ} \mathrm{C} \text {, } \\
1 \mathrm{~kg} \mathrm{KMnO} / \text { liter of resin } \\
\text { (degraded), Sample } 3,80 \mathrm{~g} \\
\text { soln, } 4.409 \mathrm{~g} \text { wet ppt }\end{array}$ \\
\hline 1915 & 2879 & 2054 & .1666 & .2505 & .0125 & .547 & $\begin{array}{l}\text { Ionac, } 15 \mathrm{hrs}, 70^{\circ} \mathrm{C} \text {, } \\
1 \mathrm{~kg} \mathrm{KMnO} / \text { liter of resin } \\
\text { (degraded), Sample } 4 \text {, } \\
87 \mathrm{~g} \mathrm{soln}, 6.07 \mathrm{~g} \text { wet } \mathrm{ppt}\end{array}$ \\
\hline 2787 & 380 & 2075 & .2174 & .0296 & .0119 & .402 & $\begin{array}{l}\text { Reillex, } 5 \mathrm{hrs}, 70^{\circ} \mathrm{C} \text {, } \\
1 \mathrm{~kg} \mathrm{KMnO} / \text { liter of resin } \\
\text { (fresh), Sample } 5,78 \mathrm{~g} \\
\text { soln, } 5.7342 \text { g wet ppt }\end{array}$ \\
\hline 3374 & 329 & 470 & .2362 & .023 & .0028 & $\begin{array}{r}.526 \\
1 \\
( \\
\mathrm{s}\end{array}$ & $\begin{array}{l}\text { Reillex, } 10 \mathrm{hrs}, 70^{\circ} \mathrm{C} \text {, } \\
1 \mathrm{~kg} \mathrm{KMnO} / \text { liter of resin } \\
\text { (fresh), Sample } 6,70 \mathrm{~g} \\
\text { soln, } 5.9426 \mathrm{~g} \text { wet ppt }\end{array}$ \\
\hline 3550 & 947 & 3 & .2449 & .0653 & 0 & $\begin{array}{r}.423 \\
1 \\
( \\
\mathrm{s}\end{array}$ & $\begin{array}{l}\text { Reillex, } 15 \mathrm{hrs}, 70^{\circ} \mathrm{C} \text {, } \\
1 \mathrm{~kg} \mathrm{KMnO} / \text { liter of resin } \\
\text { (fresh), Sample } 7,69 \mathrm{~g} \\
\text { soln, } 7.9057 \mathrm{~g} \text { wet } \mathrm{ppt}\end{array}$ \\
\hline 3456 & 3405 & 0 & .2765 & .2724 & 0 & .593 & $\begin{array}{l}\text { Ionac, } 15 \mathrm{hrs}, 70^{\circ} \mathrm{C} \\
1 \mathrm{~kg} \mathrm{KMnO} / \text { liter of resin } \\
\text { (fresh), Sample } 8,80 \mathrm{~g} \\
\text { soln, } 5.1679 \mathrm{~g} \text { wet ppt }\end{array}$ \\
\hline
\end{tabular}




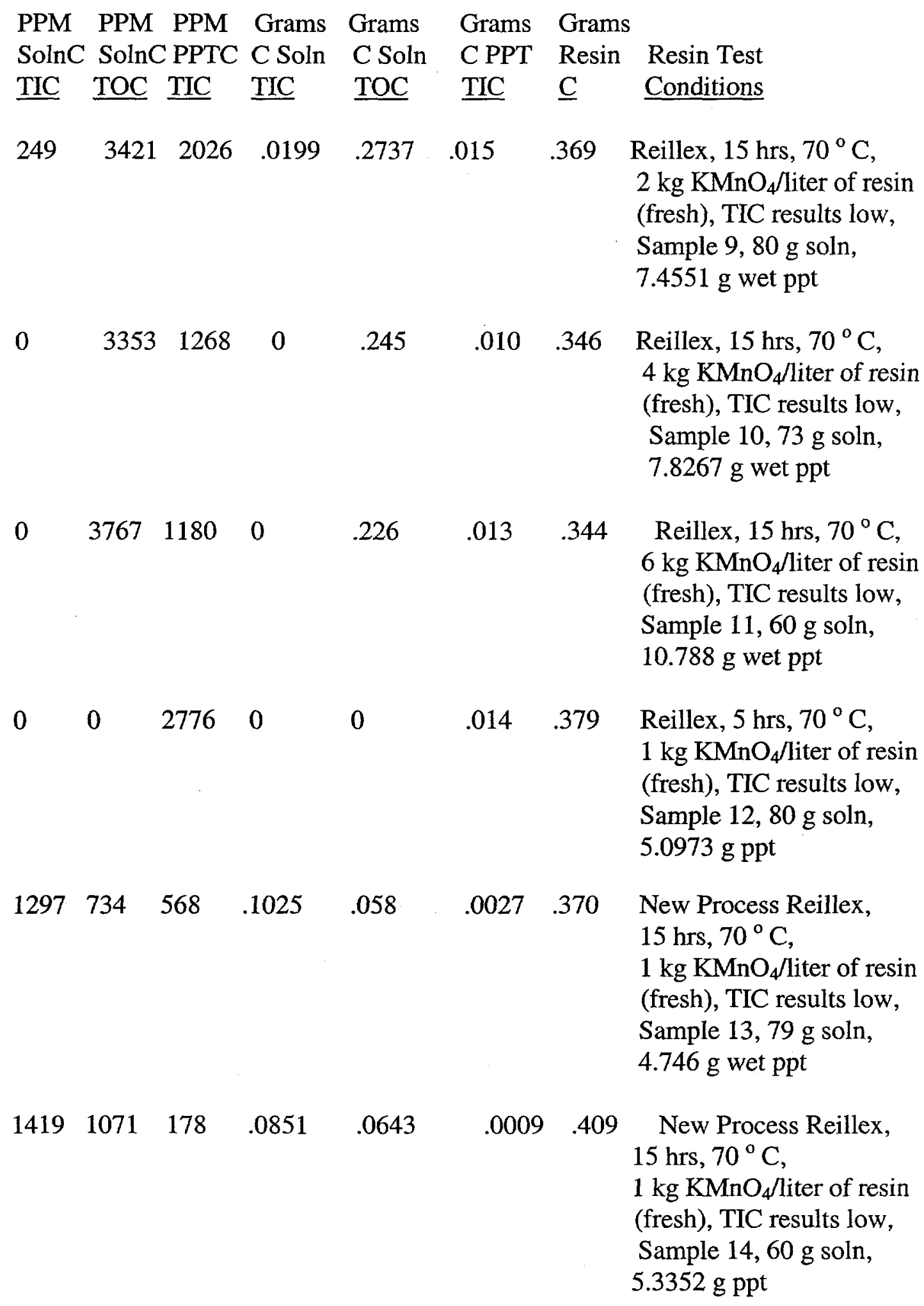

